\title{
The Influence of Job Rotation Practices on Employee Performance, Mediation Effect of Human Factor and Motivation
}

\author{
B. Ravikumar, Kokila Mohan, Vedantam Seetha Ram
}

\begin{abstract}
Banking industry plays a significant role in economic development of a nation through their operational efficiency. This study is an assessment of enhanced skills of employees through job rotation such that their performance, human factor and motivational factor play role on employee performance. A self - administered adopted questionnaire developed by Morgeson \& Humphrey, also Marylene Gagne et al., method adopted questionnaire is circulated amongst 402 employees of banks in Vellore district selected applying purposive sampling method. The data is assessed applying mediation technique using structural equation modeling approach. Results indicate that motivation and human factor play mediating role in the performance of employees due to job rotation. This study confirms the importance of job rotation in the performance of employees in banking industry helping employer build better relationship and yield effective results from their employees.
\end{abstract}

Keywords: Job Rotation, human factor, motivation, performance, mediation.

\section{INTRODUCTION} business is banking, which plays an important role in the development of the country. Banking industry plays a significant part in compressing the entire economic arrangement of an economy, as well as, it pays attention to the growth of the whole economy of a nation. India is no exception from this situation. The Indian banking sector has appeared as one of the strongest driving forces of India's economic growth and development. Indian banking industry accounts for 95 percent of the total financial sector operations (RBI, 2014a). In India an entrenched banking system is followed, which comprises of many financial institutions ranging from scheduled commercial banks, a central bank and other financial institutions such as ICICI, HDFC, HUDCO etc. are specialized in their service to cater to the detailed desires of numerous segments of the country. Today, one of the primary concerns of these commercial agencies is to motivate and inspire their employees such that their

Revised Manuscript Received on January 29, 2020

* Correspondence Author

Dr. B. Ravikumar*, Scientist in Project Planning and Business Development, CSIR - Central Leather Research Institute, Chennai.

Dr. Kokila Mohan, Department of Management studies, VIT University, Vellore

Dr Vedantam Seetha Ram, Assistant Professor, Senior Accounting and Finance, Department of Technology Management of VIT, Vellore.

(C) The Authors. Published by Blue Eyes Intelligence Engineering and Sciences Publication (BEIESP). This is an open access article under the CC BY-NC-ND license (http://creativecommons.org/licenses/by-nc-nd/4.0/)
All over the countries, the most vital and significant

performance and commitment towards work improve, thereby attainment of committed outcome [1]. [2], [3] Job rotation practice as shifting employees systematically from one job to another at scheduled intervals. In order to suit the requirements of various task, employees need to be shifted to variety of jobs which involves numerous responsibility and accountability [4], [5]. [6] Job rotation practice as shifting the employees between wider range of positions, responsibilities and tasks which will be possibly alike in nature. Many institutions including banks interchange their workers from one task to another across numerous branches for several reasons. Other operational terms that could be used interchangeably with job rotation include job changes, transfers, cross training, lateral moves, redeployment and rotational assignments. The importance of job rotation has been long recognized in almost every business setting all around the universe.

Performing variety of jobs through different sections and thorough knowledge of technical developments are required by many institutions today [7]. One of the finest method for the commercial institutions to assist their workers in order to improve the enthusiasm, work motivation and performance can be done by providing efficient teaching and learning programs at their workplace. One such training method used in banks is job rotation practices and it happens at learner's workplace, by using the same procedures, materials and methods which will remain to be utilized as the training technique on their real tasks with low cost [8].

Human factor is becoming an increasingly significant practice in the workplace. Human factor includes adapting a perfect job design strategy and provide good workplace to the employees. The economic consequences of human factors involve less absenteeism, decrease in medical costs and higher performance of employees. Studies have stated that human factors can distract employees physically and psychologically. Through work environmental changes and perfect job design, human factors can decrease strain (e.g., Physical discomfort, tiredness, and tension) in the workplace. Strain is a reaction to experienced stress that has inverse effect of human factors on organization's profitability.

Psychological stress happens when one perceives that environmental wants go beyond the competencies, actually prevailing in the organization. Experienced stress in the workplace establishes itself in poor physical health,

Published By: Blue Eyes Intelligence Engineering

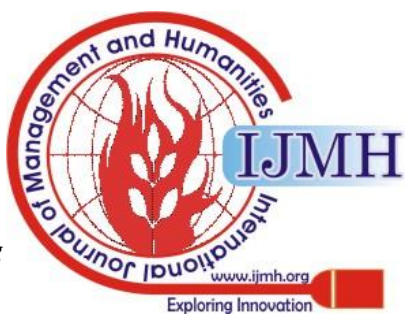


poor mental health, and is related with organizational symptoms such as low performance, job dissatisfaction, absenteeism and turnover. When the human factors are taken care, the employees can explore well and their performance will improve.

This study aims to provide the empirical understanding regarding the extent to which job rotation programs and human factors, motivate the employees working in banking companies of India and how much involved and committed are the employees of the bank, making understand the advantages of rotation and training. This research enlightens operational executive's views regarding the significance of job rotational activities, human factors and its contribution towards employee motivation and performance in banking industry.

\section{REVIEW OF LITERATURE AND HYPOTHESIS}

In recent years, many institutions including banks are rotating their workers from one task to another across numerous branches for several reasons [2], [3]. There are many alternate terms that are used for job rotation practices and that comprise of job change, relocation, cross training, adjacent moves, redeployment and rotational assignments. This sort of change in the work is a significant training practice in every business across the globe [4], [5].

Job rotation is an outstanding technique for the institutions to improve workers, bosses and executive's skills [4]. This job rotation practice allows the efficiency of existing workers to act as a database for other segment of workers, so that the institution has supplementary dynamic workforce and acts as organized source of qualified and skilled labour that helps as a modest authority for the institution [9]. [10] Job rotation as a practice of developing worker's skill in solving their issues at work place and a tool of improving knowledge about the work performed, which in turn improves group competency that allows them in maximizing promotion chances. Thus, both the workers and bosses can gain help from job rotation practices in the institution. When job rotation is practiced in the organization, the top management should pay attention on the excellence of person's effort participation moderately than amount of tasks performed by the employees. At the same time, consequent rotation design must be organized conferring to the capability competence and alternate time to the employees at work [1].

Job rotation is the appropriate practice to be followed which makes an organization to be a learning organization [11]. [12] The author analyzed various costs involved in practicing job rotation in an organization. The main advantage of practicing job rotation is; it is a learning instrument with which the institution can study employees' output and performance of diverse tasks. [13] The author studied that involving employees in the job redesigning process is a best management initiative and the authors also found out key issues which makes employees to stop from participation in Job redesign process are knowledge of participants, coverage of sensitive issues, cross-section of participants, organizational context, role of workshop facilitator etc. The authors arrived at a conclusion that employees should be motivated by the management to enhance their participation in job designing process.
Job rotation practice is a technique of work craft method which permits workforce to study the work abilities from numerous divisions and removes the workers' tiredness triggered through similar nature of work projects [14]. The challenges faced by the workers in novel tasks can inspire them to expand eagerness and increase the employee's self-esteem in the job atmosphere. [1] The author suggested that applying job rotation practice as an engineering technique that is helpful in manufacture competence, decrease of labour cost, worker happiness, and decrease in Work-related Musculoskeletal Disorders (WMSDs) amongst employees.

[15] The author arrived at a conclusion in their study that there are three probable descriptions for the organizations to adopt job rotation practices. They are employee's knowledge, employer knowledge and worker motivation. Job rotation technique is very often applied by organizations, where organizations are spending more resources on training employees. Further, job rotation practices are commonly used in organizations having smaller average worker time bound.

[16] They analyzed that well- designed tasks can take an optimistic influence on both employee satisfaction and performance excellence. The authors also projected that the employee performance, motivation and satisfaction can be improved with the help of well-defined tasks assigned to the workers. Therefore, for both industrial experts and academicians, work designing procedure in organization has an extraordinary significance in trending Human Resource Management (HRM) for being successful in the competitive world. Job rotation practice is an excellent strategy for manpower utilization in hospitals. Decrease of work uncertainty in job pressure has the greatest impact on increasing organizational commitment of nurses. The significant aim was to improve retention rate and job satisfaction of nurses and make them to retain in their job [4]. [3] The authors determined in their investigation that the organizational assurance of the worker increases when the jobs are redesigned according to the employee's requirement. Constantly changing work environments in the organization bring more commitment and self- perseverance among employees. The job characteristics model plays a vibrant role in job redesigning process where the jobs immensely involve skill variety, task significance, task identity, autonomy, and feedback.

The present study had found that skill variety, task significance, task identity, autonomy, and feedback are the components of job rotation practice which influence the performance of employees. These components were taken into consideration to test the following hypothesis.

H1: Job rotation practices will have a positive effect on performance. Human factor is also known as ergonomics. Human factors deal with a system of interrelating mechanism that includes employees and work atmosphere; both physical and organizational, job and workstation. The aim of human factors is to confirm a good fit between the employees and their work, thereby maximizing employee well-being, security, efficiency and competence.

Blue Eyes Intelligence Engineering

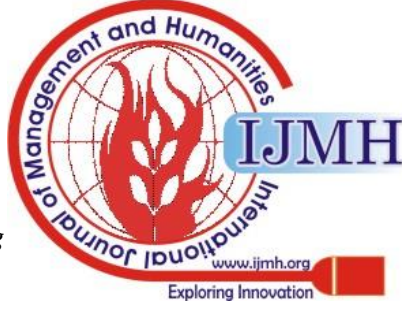


The arguments that support a good human factors management system cannot be ignored. In today's market condition most of the organization obtains competitive advantage through their quality and excellence.

Such organizations identify the human factor as the most valuable resource to be managed for cost saving, quality development and performance. Further, it has been described in expansive terms, the components and activities required to implement human factors management.

Improved human factors management is both a realistic goal and good business. The multidisciplinary approach to Human Factor and Ergonomics will pave the way for development in work culture. The pain and stress are higher for banking employees than any other sedentary work employees. The banking industry shall develop human factor rules along with job rotation practices and create tools to assist banking professionals in developing effective ergonomic programs [17]. Ergonomic problems will affect the employees in negative way which reduces the overall productivity and performance. Ergonomic factor is the important factor used in all organization to have expected productivity outcome. Employee involvement and satisfaction increase, when the ergonomic issues are cleared by the management [18], it is assumed that job rotation practices will have positive influence on human factor.

$H 2$ : Job rotation practices will have positive effect on human factor.

The goal of human factor/ergonomics is to fix the job to an individual and not individual to the job. Practicing good human factor attains increased productivity, improved health and safety of workers, improved job satisfaction and good compliance with government regulations. The general human factor values be applied to the workplace, that contain dynamic and fixed work environment. Also, the human factor values concentrates on enhancing work surface heights, avoiding overwork of muscles, avoiding unusual postures, training individuals to use the workplace efficiently and appropriately. further the important components of human factor includes anthropometry, chair design, manual resources handling, and focuses on most common musculoskeletal disorders (MSDs) such as increasing pain complaints and lower back damages. When the organization takes care on the human factor issues the employees performance increases [6]. Thus, this study proposes that human factor is related to performance.

H3: Human Factor will have a positive effect on performance.

Motivation directly relates to worker performance that gain to organization performance and as a catalyzer for all workers working for an organization to develop their job performance and to finish task in a better method than they generally do [7]. Institutions works for efficient employees occupied for it, and separately each individual pays towards attaining the final objective of an Institution. [19] They proposed a model of the association between cognition and motivation that integrates social features of the learning setting, students' prior accomplishment, cognitive variables (learning plans, background knowledge, self-regulation, metacognition) and motivational variables (e.g., expectations, standards). This also portrays motivation as being affected and both affecting by cognition, and together in turn, disturbed by societal perspective. The model also depicts motivation and cognition as disturbing attainment and engagement of employees. Therefore,

H4: Job rotation will have a positive effect on motivation.

[5] The authors instigated that with external motivation, there persist an important interface among stress relieving activity, flexible working time, and nation of habitation. Top management distinguish that at the nature of each work, creativeness and effective commercial deceits in a flourishing institutional culture and meticulous persons who work for the organization cooperate fervently to yield excessive outcomes [20]. [1] Author profound a prosperous institution must associate the metrics and inspirations of inner workers and reply to outside fluctuations and need quickly to illustrate the institution's significance. In this article, the author has engaged numerous methods of inspiration and motivation from prevailing review of literature, and succeeded to mark easy flow of inspiration and motivation starts fresh workers to old workers. From the organization's viewpoint, supervisor's necessity is to recognize the flow of inspiration and motivation had given in the organization and that will help them to generate a culture where workers always get motivated to do enhanced performance.

H5: Motivation will have a positive effect on performance.

Mediation Effects: As stated earlier, job rotation practices will increase employee performance with the help of human factor activities. Similarly, job rotation practices will increase employee performance with the help of motivation (performance of banking employees is enhanced and the development in their activities is clearly visible). Therefore, the following hypotheses are put forward;

H6: Human Factor will mediate the relationship between job rotation practices and performance.

H7: Motivation will mediate the relationship between job rotation practices and performance.

The research framework to deliberate the objective of this study is given in Figure: 1. It is discussed that job rotation practices are related to performance, human factor and motivation. Additionally, human factor and motivation have a direct effect on performance (see Figure: 1).

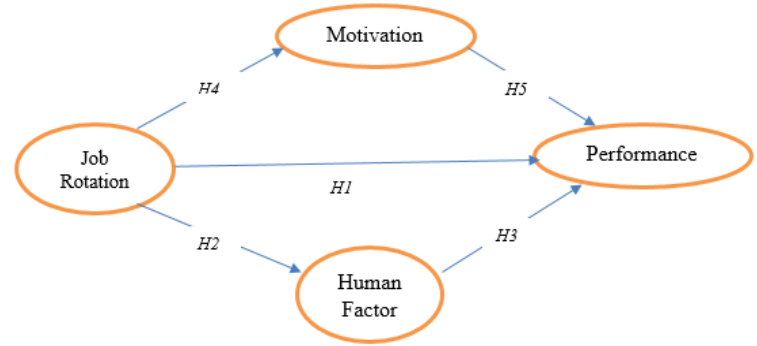

Fig. 1. Conceptual Framework

\section{METHODOLOGY}

\section{Context}

In India, there are 21 public sector banks and 20 Private sector banks (Indian Banker's Association website).

Published By:

Blue Eyes Intelligence Engineering

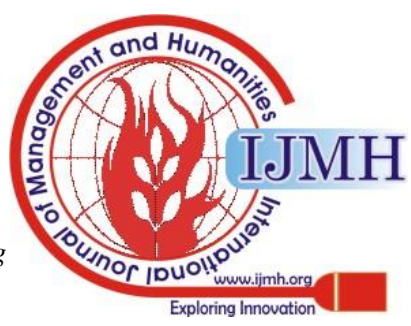


The primary data is collected from various branches of 8 public and 3 private banks of Vellore district using structured questionnaire. In order to preserve the confidentiality, the names of the banks are not disclosed in this paper. As the data is highly confidential, responses are provided by the operational employees under strict supervision and controlled environment.

\section{Data collection and sample}

Subjects: a well-defined and a structured questionnaire is administered to collect the primary data required for testing the conceptual model. The primary data is collected from operational level executives in public and private sector banks of Vellore district. The sampling technique is based on purposive sampling. As per the purposive sampling method; the researcher had selected 402 respondents in which 283 from public sector banks and 119 from private sector banks of the total operational employees in the banks at random for achieving at the reliability and validity of the data collected. The operational executives include the teller, loan officer, clerk (admin duties) and probationary officer of the banking industry.

\section{Measures}

The variables in the conceptual model is measured with the help of five point likert scale from 1= "Strongly Disagree" to 5= "Strongly Agree". The measurement scale is adopted and modified from the earlier studies. The questionnaire of job rotation and human factor is adopted from Work Design Questionnaire (WDQ scale) [21]. The scale of motivation is adopted from Multidimensional Work Motivation Scale (MWMS) [22]. The overall performance is measured using the revised questionnaire taken [23] for the current study.

\section{Data analysis}

To assess the relationship in the conceptual model, Covariance based Structural Equation Modelling (SEM) with the help of AMOS 18.0 and maximum likelihood assessment is used. To estimate the psychometric possessions of the scales confirmatory factor analysis (CFA) is done such that it helps in testing the discriminant validity of the measures. According to the procedures given by authors [24], the first stage of analysis consisted of factor validity of each construct.

\section{RESULTS AND DISCUSSION}

Initially, each item's factor loading is analyzed and the results clearly indicate that all the items factor loadings are greater than 0.5 after CFA first run. The test statistic shows that, the measurement model applied in this study indicates that the data fits clearly to the model. The model values are $\mathrm{CMIN}=476.73$, df $=225, \mathrm{p}=0.000, \mathrm{CMIN} / \mathrm{df}=2.11$. The model fit values are; $\mathrm{CFI}=0.801, \mathrm{GFI}=0.847$, $\mathrm{TLI}=0.906$ and RMSEA $=0.065$. The worldwide used reliability method is internal consistency reliability method, which is measured with the help of Cronbach's alpha value. The scale reliability is Job Rotation $=0.90$, Human Factor $=0.89$, Motivation $=$ 0.85 , Performance $=0.82$. According to [25], the widely used thumb rule for utilizing reliability is greater than 0.5 and hence the measurement scale values are highly reliable.

The next stage of analysis is testing the convergent validity of the data. To do so, each items factor loadings and the average variance extracted (AVE $>0.5$ ) values are checked. The factor loadings of each item is significant, i.e. $p$ value $>0.5$ [25] and the AVE values are $>0.5$ (Table: 3). so, the convergent validity of latent variable is proved. According to the suggestion of authors [26] discriminant validity is checked. To check the discriminant validity, the AVE value should be greater than the corresponding squared inter-construct correlation values between the two constructs. In this paper it is found that all the AVE values are exceeding the corresponding squared inter construct correlation values. The latent variable correlation matrix is shown in Table: 1.

Table - I: Correlation matrices

\begin{tabular}{lcccc}
\hline & $\begin{array}{l}\text { Human } \\
\text { Factor }\end{array}$ & $\begin{array}{l}\text { Job } \\
\text { Rotation }\end{array}$ & Motivation & Performance \\
\hline Human Factor & 1.000 & & & \\
Job Rotation & 0.275 & 1.000 & & \\
Motivation & 0.322 & 0.139 & 1.000 & \\
Performance & 0.223 & 0.219 & 0.126 & 1.000 \\
\hline
\end{tabular}

Figure 2 shows all the relationships among the variables, path coefficients and their significance, $\mathrm{R}$ square for each dependent variable is presented.

\section{Mediating Effect}

To ascertain the estimates of indirect effect and to check the significance level by using confidence intervals, bootstrapping process is implemented. At 95 percent confidence interval estimates, if zero does not included it refers that the indirect effect of the variables are statistically significant. In the current study, there are two mediating variables in the conceptual model, so the results are shown separately. To do so, [27] phantom variables and bias-corrected bootstrap technique is applied. The investigator instructed AMOS to create 2000 sample for bootstrapping and select the bias-corrected bootstrap technique with 95 percent confidence interval.

In the initial phantom model, the indirect effect is significant $(\mathrm{p}<0.001)$, the point estimate is 0.143 with bias corrected lower and upper limit confidence interval are 0.049 and 0.840 , here zero does not lies between the interval value which confirms that human factor mediates the relationship between job rotation and employee performance. In the second phantom model also, the indirect effect is significant $(\mathrm{p}<0.001)$. The point estimate is 0.186 with bias corrected lower and upper limit confidence interval values are 0.115 and 0.847. Therefore it shows motivation mediates the relationship between job rotation and employee performance. These results are shown in Table 3 . Hence both human factor and motivation have significant mediating effect between job rotation and employee performance.

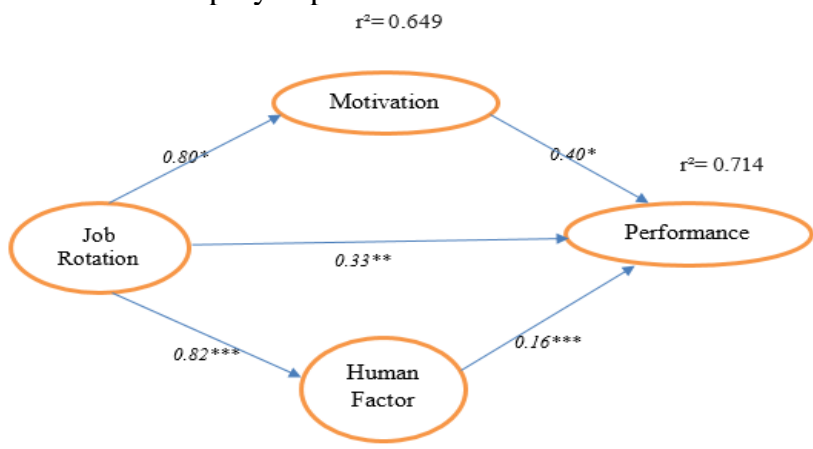

Fig. 2. Validated Model $\left({ }^{*} \mathbf{p}<=0.05,{ }^{*} \mathbf{p}<0.01, * * * p=0.001\right.$

Blue Eyes Intelligence Engineering

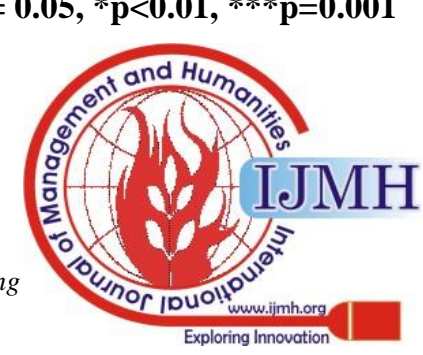


The findings of this current study confirm that job rotation practices will have an impact on employee performance, human factor and motivation.

Table II. Summary of results

\begin{tabular}{|c|c|c|c|}
\hline \multirow[t]{2}{*}{ Hypotheses } & Path & t-value & \multirow{2}{*}{$\begin{array}{l}\text { Test } \\
\text { Result }\end{array}$} \\
\hline & Estimates & & \\
\hline $\begin{array}{l}\text { H1: Job rotation practices will have a } \\
\text { positive effect on }\end{array}$ & 0.336 & 5.61 & Accepted \\
\hline $\begin{array}{l}\text { H2: Job rotation practices will have } \\
\text { positive effect on human factor. }\end{array}$ & 0.826 & 3.04 & Accepted \\
\hline $\begin{array}{l}\text { H3: Human Factor will have a } \\
\text { positive effect on performance. }\end{array}$ & 0.161 & 2.18 & Accepted \\
\hline $\begin{array}{l}\text { H4: job rotation will have a positive } \\
\text { effect on motivation. }\end{array}$ & 0.806 & 6.78 & Accepted \\
\hline $\begin{array}{l}\text { H5: motivation will have a positive } \\
\text { effect on performance. }\end{array}$ & 0.401 & 5.94 & Accepted \\
\hline
\end{tabular}

Table III. Mediation effects

\begin{tabular}{lllll}
\hline Hypotheses & $\begin{array}{l}\text { Independent } \\
\text { Variable }\end{array}$ & Effect & Significance & Test Result \\
\hline H6 & $\begin{array}{l}\text { Human } \\
\text { Factor }\end{array}$ & 0.143 & 0.001 & Accepted \\
H7 & Motivation & 0.186 & 0.001 & Accepted \\
\hline
\end{tabular}

Note: Mediator, Human factor and Motivation; dependent variable, performance. Significance is based on bootstrapping techniques.

The current study supports the notion that job rotation practice which is a part of job design approach and is a fundamental driver of employee performance because of the commitment and interest the employees have in their job [28]. The findings of current study are in line with the previous research which indicates that job design is the root cause of an employee performance. This study also supports that job rotation practice is an effective job design activity to develop interest amongst employees and to improve their performance on their job.

The current study also examines the mediating effect of human factor and motivation on the relationship between job rotation and performance. This yields a new insight how the human factor and motivation increases the employee performance. Based on the findings, the conceptual framework has shown a positive effect on all the variables. That means job rotation has been influential to performance with the help of human factor and motivation. According to author [29], any organization that needs to improve their employee's satisfaction and performance, should concentrate on hygiene and motivating factors as well and both should move hand in hand. The findings of this study also reveal the same idea of Herzberg's two factor theory. Thus the results are positively related to all the variables and prove that there exists a good relationship among the selected study variables.

\section{CONCLUSION}

The present study revealed that banks shall have systematic way of applying job rotation for operational executives which is not in existence at present. At present in banks, digitalization is given higher priority than the human factor and their facilities. But this study found out that there exist a strong relationship between human factor and motivation. This paper also revealed that there exist a strong relationship between motivation and performance. There may be absenteeism, employee turnover prevailing among the workforce in banks, but such factors can be overcome if motivation is provided by way of job rotation practices for enhancing motivation and performance. The conclusive evidence of this study is also statistically proved in the hypothesis statements where the present situations in banks have to undergo a lot of thought process in implementing job rotation practices for gaining higher performance results leading to high productivity and profits in order to bring innumerable benefits to the society, country and also for improving economic growth.

Even though the current study is conducted in a limited geographic region i.e. Vellore District with difficulties in data collection, number of banks and type of banks considered is limited, future research can look into foreign banks as well; as their presence in this district is zero and conduct a comparative study for better results. Measurement of this study is subjective and is based on employee personal experiences, which is not free from bias. Further, the study can concentrate on various factors that contribute to employee performance rather human factor and motivation alone.

\section{APPENDIX}

Table AI. Item statistics and measurement model results

\begin{tabular}{|c|c|c|c|c|c|c|c|}
\hline Item & Constructs & Nean & SD & Loadings & $\begin{array}{c}\text { Cronbach's } \\
\text { a. }\end{array}$ & AVE & $\begin{array}{l}\text { Composite } \\
\text { Reliability }\end{array}$ \\
\hline \multicolumn{8}{|c|}{ Job Rotation } \\
\hline$J_{\mathbb{1}}$ & Autonomy & 4.27 & .62 & .73 & 0.90 & 0.60 & 0.90 \\
\hline $\mathrm{JR} 2$ & Task variety & 4.36 & .62 & .49 & & & \\
\hline $\mathrm{JR} 3$ & Task significance & 4.22 & .67 & .63 & & & \\
\hline $\mathrm{JR} 4$ & Task identity & 4.27 & .64 & .71 & & & \\
\hline $\mathbb{R} 5$ & Feedback & 4.35 & .61 & .74 & & & \\
\hline $\mathbb{J R} 6$ & $\begin{array}{l}\text { Information } \\
\text { Processing }\end{array}$ & 4.25 & .67 & .69 & & & \\
\hline $\mathbb{R}\}$ & Problem solving & 4.22 & .68 & .65 & & & \\
\hline JRS & Skill variety & 4.27 & .66 & .69 & & & \\
\hline $\mathbb{R} \theta$ & Specialization & 4.23 & .67 & .71 & & & \\
\hline \multicolumn{8}{|c|}{ Human Factor } \\
\hline $\mathrm{HF} 1$ & Social support & 4.23 & .66 & .72 & 0.89 & 0.59 & 0.89 \\
\hline HF2 & Ergonomics & 4.32 & .63 & .70 & & & \\
\hline $\mathrm{HF} 3$ & Physical demand & 4.31 & .65 & .77 & & & \\
\hline HF4 & work conditions & 4.34 & .60 & .79 & & & \\
\hline HF5 & Equipment use & 4.27 & .66 & .72 & & & \\
\hline \multicolumn{8}{|c|}{ Motivation } \\
\hline NoTn & Basic need & 4.24 & .67 & .69 & 0.85 & 0.56 & 0.85 \\
\hline NoT12 & Safety & 4.33 & .61 & .75 & & & \\
\hline NOT13 & Self esteem & 4.35 & .62 & .68 & & & \\
\hline NOTI4 & Affection & 4.32 & .63 & .72 & & & \\
\hline NOT15 & Self-Actualization & 4.33 & .65 & .67 & & & \\
\hline \multicolumn{8}{|c|}{ Pevformance } \\
\hline PERF1 & $\begin{array}{l}\text { Declarative } \\
\text { knowledge }\end{array}$ & 4.35 & .64 & .67 & 0.82 & 0.61 & 0.82 \\
\hline PERF2 & $\begin{array}{l}\text { Procedural } \\
\text { knowledge }\end{array}$ & 4.33 & .64 & .71 & & & \\
\hline PERF3 & Level of effort & 4.38 & .67 & .66 & & & \\
\hline PERF4 & Choice to perform & 4.38 & .64 & .71 & & & \\
\hline
\end{tabular}

Note: $\mathrm{CMIN}=476.73, \mathrm{df}=225, \mathrm{p}=0.000, \mathrm{CMNN} / \mathrm{df}=2.11, \mathrm{RMR}=0.122, \mathrm{CFI}=0.801, \mathrm{GFI}=0.847, \mathrm{AGFI}$ $=0.831, \mathrm{NFI}=0.885$, TLI $=0.806$ and RMSEA $=0.065$

\section{REFERENCES}

1. Campion, M., L. Cheraskin, and M. Stevens (1994). Career-Related Antecedents and Outcomes of Job Rotation, Academy Of Management Journal, Vol.37, No.6, pp. 1518-1542.

2. Malinski R.M (2002). Job Rotation in an Academic Library: Damned If You Do and Damned If You Don't, Lib. Trends, Vol. 50, No.4, pp. 673-80.

3. Dessler G and B. Varkkey (2009). Training and Development. Human Resource Management. New Delhi: Dorling Kindersley (India) Pvt. Ltd, p. 304.

4. Beatty, R., C. Schneier, and G. Mcevoy (1987). Executive Development and Management Succession, Research in Personnel and Human Resources Management, Vol.5, pp.289-322.

5. Dias, R., Robbins, T. W., \& Roberts, A. C. (1996). Dissociation in prefrontal cortex of affective and attentional shifts. Nature, 380(6569), 69.

Published By:

Blue Eyes Intelligence Engineering

\& Sciences Publication

DOI:10.35940/ijmh.F0579.024620

Journal Website: www.ijmh.org

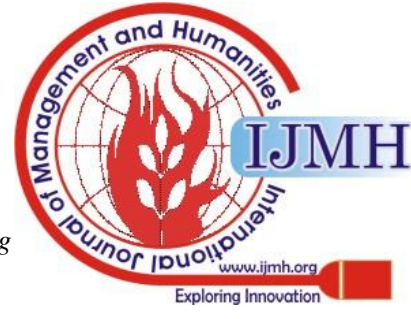


6. Torrington D, Hall L (1991). Personal Management New Approach. New York: Prentice Hall, pp. 285.

7. Snow C.C, R.E Miles and H.J Coleman (1992). Managing 21 Century Network Organizations, Org. Dynamics, Vol.21, No.3, pp. 5-20

8. Kamery R.H. (2004). Motivational Techniques for Positive Reinforcement: Review, Allied Acad. Int. Conf., Vol.8, No.2, pp. 91-96

9. Rothwell W.J and H.C Kazanas (1994). Improving On-The-Job Training: How to Establish and Operate a Comprehensive on Job Training Program. San Francisco: Jossey Bass, Vol. 3, No.3, pp.319-324.

10. Faegri T, T. Dyba and T. Dingsoyr, (2010). Introducing Knowledge Redundancy Practice in Software Development: Experiences with Job Rotation in Support Work, Inf. Software Tech., Vol. 52, pp. 1118-1132.

11. Kurtulus Kaymaz (2010).The effects of job rotation practices on Motivation: A research on managers in the automotive industry, Business and Economics Research Journal, Vol. 1,No. 3

12. Jaime Ortega, (2001). Job Rotation as a Learning Mechanism, Management Science, Vol.47, No.10, pp.1361-1370

13. Nadin S.J., P.E. Waterson and S.K. Parker (2001). Participation in job redesign: An evaluation of the use of a sociotechnical tool and its impact, Human Factors and Ergonomics in Manufacturing \& Service Industries, Vol. 11, No. 1,.pp. 53-69.

14. Jorgensen, M. (2005). Characteristics of job rotation in the Midwest US manufacturing Sector. Ergonomics, Vol.48, No.15, pp. 1721-1733

15. Eriksson T. and J. Ortega (2006). The Adoption of Job Rotation: Testing the Theories, Ind. Labour. Rel. Rev., Vol. 59, pp. 653-666.

16. Pooja Garg and Renu Rastogi (2006). New model of job design: motivating employees' performance, Journal of Management Development, Vol. 25, No. 6, pp. 572 - 587.

17. Marnie Myhre (2012). Symposium on Human Factors and Ergonomics in Health Care, pp. 245-259.

18. Arun, Cijo and Vinod (2013). Improvement of Ergonomic Factors That Affects Employees in a Textile Industry, International Journal of Engineering Science and Innovative Technology (IJESIT), Vol. 2, No. 1.

19. Linnenbrink, Elizabeth A; Pintrich, Paul R. (2002). Motivation as an enabler for academic success, School Psychology Review, Vol. 31, No.3, pp. 313.

20. Gignac, G. E., \& Palmer, B. R. (2011). The Genos employee motivation assessment. Industrial and Commercial Training, 43(2), 79-87.

21. Frederick P. Morgeson and E. Stephen Humphrey (2006). The Work Design Questionnaire (WDQ): Developing and Validating a Comprehensive Measure for Assessing Job Design and the Nature of Work, Journal of Applied Psychology, Vol. 91, No. 6, 1321-1339.

22. Marylene Gagne A, Jacques Forest and Maarten Vansteenkiste (2015). The Multidimensional Work Motivation Scale: Validation Evidence in Seven Languages and Nine Countries, European Journal of Work and Organizational Psychology, Vol. 24, No. 2, pp. 575-785.

23. Campbell, C. H., P., Ford, M. G., Rumsey, E. D., Pulakos, W. C., Borman, D. B., Felker, M. V., DeVera, and B. J. Riegelhaupt. (1990). Development of multiple job performance measures in a representative sample of jobs. Personnel Psychology, Vol.43, pp. 277-300.

24. Byrne, B. M. (2001). Structural equation modeling: Perspectives on the present and the future. International Journal of Testing, 1(3-4), 327-334.

25. Hair, E., Halle, T., Terry-Humen, E., Lavelle, B., \& Calkins, J. (2006). Children's school readiness in the ECLS-K: Predictions to academic, health, and social outcomes in first grade. Early Childhood Research Quarterly, 21(4), 431-454.

26. Fornell, C., \& Larcker, D. F. (1981). Structural equation models with unobservable variables and measurement error: Algebra and statistics. Journal of marketing research, 382-388.

27. Mallinckrodt, B., Abraham, W.T., Wei, M. and Russell, D.W. (2006), "Advances in testing the statictical significance of mediation effects", Journal of counselling psychology, Vol. 53 No. 3. P.372.

28. Rajala Schultz, P. J., and G. S. Frazer, (2003). Reproductive performance in Ohio dairy herds in the 1990s, Animal Reproduction Science, Vol. 76, No. 3, pp. 127-142.

29. Herzberg, F. (1964). The motivation-hygiene concept and problems of manpower. Personnel Administration.

\section{AUTHORS PROFILE}

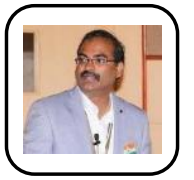

Dr. B. Ravikumar, is working as Scientist in Project Planning and Business Development, CSIR - Central Leather Research Institute, Chennai. He holds a doctoral degree from Department of Statistics, Manonmaniam Sundaranar University, Tirunelveli. He has 12 years of Teaching and 1 year of Industrial experience. He published ten research papers in national and international journal of repute and presented papers in eight conference. He performed as reviewer in the journal of Applied Statistics. He has conducted six national level workshops on Data Analysis and Statistics. He has been a resource person for several workshops and FDP programs.

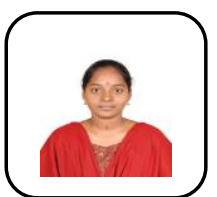

Dr. Kokila Mohan, is a freelancer and management consultant. She holds a Doctoral degree from Department of Management studies, VIT University, Vellore on job designing activities. She worked as a Research associate in the ICSSR funded project, funded by Ministry of HRD. She published five international research papers in reputed journals, one book chapter and participated and presented papers in six conferences of management studies.

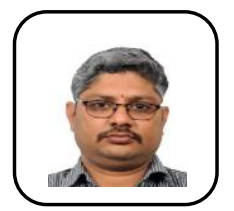

Dr Vedantam Seetha Ram. is an Assistant Professor Senior in Accounting and Finance with Department of Technology Management of VIT, Vellore. He holds a doctoral degree from Department of Commerce and Management, Andhra University on corporate reporting practices in India. He has 11 years of Teaching and 2 years of Industrial experience. He published three national, nine international research papers in journals of repute, three book chapters and participated and presented papers in more than 25 conferences of national importance in finance. He acted as reviewer for international journals and doctoral thesis of several universities and successfully guided two doctoral graduates and acted as resource person for several FDPs and MDPs, having research interest in Corporate, Behavioural and Neuro Finance domains.
Published By: Blue Eyes Intelligence Engineering \& Sciences Publication (C) Copyright: All rights reserved.

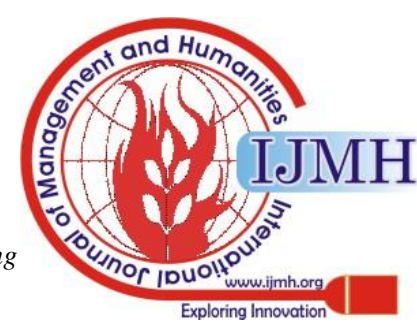

